\title{
Dentigerous cyst arising from a complex odontoma: an unusual presentation
}

\author{
Kapil Dagrus, ${ }^{1}$ Sharad Purohit, ${ }^{2}$ Bhari Sharanesha Manjunatha ${ }^{3}$
}

'Department of Oral Pathology, KM Shah Dental College, Vadodara, Gujarat, India ${ }^{2}$ Department of Oral Pathology \& Microbiology, Jodhpur Dental College and Hospital, Jodhpur, Rajasthan, India ${ }^{3}$ Department of Dental Anatomy \& Oral Biology, Basic Dental Sciences, Faculty of Dentistry Al-Hawiyah, Al Taif21944, University of Taif, Kingdom of Saudi Arabia

\section{Correspondence to}

Professor Bhari Sharanesha Manjunatha,

drmanju26@hotmail.com

Accepted 4 April 2016

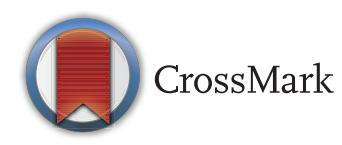

To cite: Dagrus $K_{\text {, }}$ Purohit S, Manjunatha BS. BMJ Case Rep Published online: [please include Day Month Year] doi:10.1136/ bcr-2016-214936

\section{DESCRIPTION}

A 21-year-old man presented with pain in the right posterior region of the jaw for 10-15 days. The pain was mild, dull and non-radiating in nature, beginning with slight pressure and relieved within seconds. Clinically, the patient was healthy with an unremarkable medical history. On inspection, the patient had congenitally missing mandibular molar teeth along with absence of clinical swelling intraorally. Panoramic radiograph showed an amorphous, dense, irregularly shaped radio-opacity surrounded by a well-defined radiolucency in the apical region of 46, 47 and 48, which extended anteriorly to involve an impacted mandibular first molar tooth (figure 1). Complete surgical excision was performed and tissue sent for histopathological examination. The soft tissue was separated from the calcified mass during the surgical removal. The cystic and calcified components needed different processing techniques for further investigations and hence each tissue sample was processed separately.

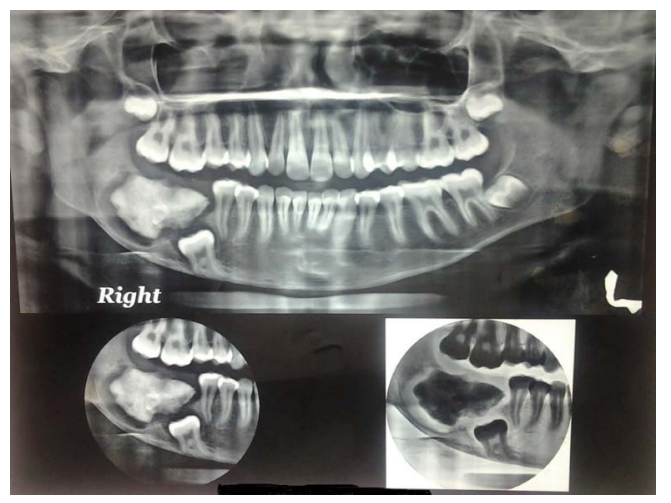

Figure 1 Panoramic radiograph showing mixed radio-opaque mass with a radiolucent rim associated with impacted mandibular molar.

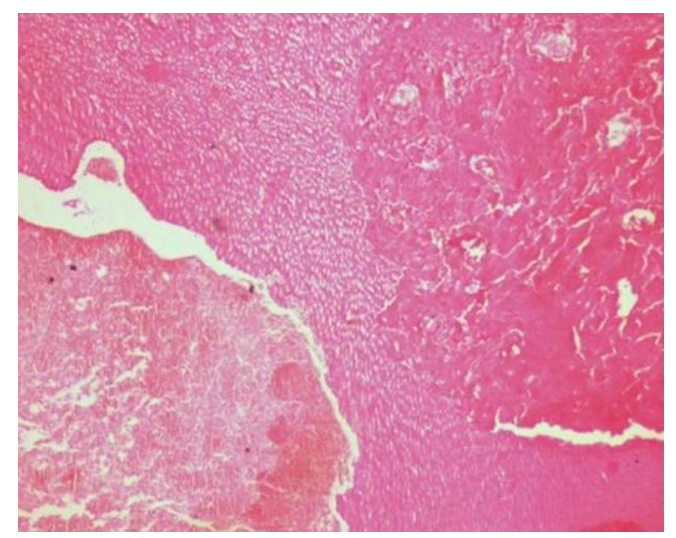

Figure 2 Photomicrograph of H\&E stained section reveals haphazardly arranged eosinophilic stained material with a dentin-like structure.

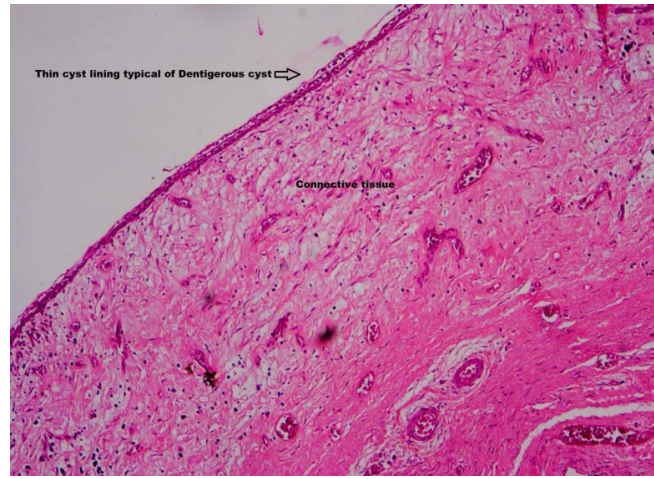

Figure 3 Photomicrograph H\&E stained section showing a thin, non-keratinized epithelial lining similar to dentigerous cyst lining.

The microscopic examination of the hard tissue of the decalcified sections revealed eosinophilic material with a dentin-like structure (figure 2). The soft tissue was thin, non-keratinised epithelial cystic lining typical of a dentigerous cyst (figure 3). A final diagnosis of 'dentigerous cyst from a complex odontoma' was rendered.

Odontomas are non-aggressive hamartomatous developmental malformations or lesions of odontogenic origin of unknown aetiology. ${ }^{12}$ They often remain asymptomatic and undiscovered until revealed by routine radiography. ${ }^{3}$

Dentigerous cyst is developmental in origin, mostly associated with an unerupted tooth or rarely on occasion with an odontoma. ${ }^{1}$ When they occur concurrently, there is possibility of the combined lesion attaining a larger size and potential for significant jaw destruction. ${ }^{1}{ }^{2}$ The potential for

\section{Learning points}

- Dentigerous cyst and complex odontoma are the most common odontogenic lesions occurring in the oral cavity and are seldom seen concurrently, resulting in misdiagnosis/ dilemma.

- Despite the reported literature, dentigerous cysts arising from odontomas are rare entities and can cause significant jaw destruction.

- Few reports show neoplastic transformation such as ameloblastomas originating from dentigerous cysts. Hence the enumerated potential complication justifies its radiographical evaluation followed by confirmation of diagnosis by histopathological analysis for better prognosis. 


\section{Images in...}

neoplastic change and invasion beyond the cyst wall justifies complete enucleation of the dentigerous cyst and underscores the importance of a histopathological examination.

Competing interests None declared.

Patient consent Obtained.

Provenance and peer review Not commissioned; externally peer reviewed.

\section{REFERENCES}

1 Astekar M, Manjunatha BS, Kaur P, et al. Histopathological insight of complex odontoma associated with a dentigerous cyst. BMJ Case Rep 2014;2014:pii: bcr2013200316

2 Wood NK, Goaz PW, Lehnert JF. Mixed radiolucent-radiopaque lesions associated with teeth. In: Wood NK, Goaz PW, eds. Differential diagnosis of oral and maxillofacial lesions. 5th edn. St. Louis, MO: Mosby, 1997:423.

3 Singh V, Dhasmana S, Mohammad S, et al. The odontomes: report of five cases. Natl J Maxillofac Surg 2010;1:157-60.

Copyright 2016 BMJ Publishing Group. All rights reserved. For permission to reuse any of this content visit http://group.bmj.com/group/rights-licensing/permissions.

BMJ Case Report Fellows may re-use this article for personal use and teaching without any further permission.

Become a Fellow of BMJ Case Reports today and you can:

- Submit as many cases as you like

- Enjoy fast sympathetic peer review and rapid publication of accepted articles

- Access all the published articles

- Re-use any of the published material for personal use and teaching without further permission

For information on Institutional Fellowships contact consortiasales@bmjgroup.com

Visit casereports.bmj.com for more articles like this and to become a Fellow 